\title{
Genetic Diversity Variation based on RAPD and Specific Markers of some Citrus Species
}

\author{
Hala M. El-Khayat
}

Horticulture Research Institute, Egypt

\author{
Received: 20 Dec. 2019 / Accepted 11 Mar. 2020 / Publication date: 20 Mar. 2020
}

\begin{abstract}
The present study was conducted in 2016 season in order to study genetic diversity of eight citrus cvs, four sweet orange (Citrus sinensis L. Osbeck) cvs named: Balady, Blood orange (Ahmar bedamo), Khalili, and red Khalili (Khalili ahmar) and four lemon and lime cvs named: Eurkea lemon (Citrus limon), lime cvs Shaery lime and Egyptian lime (Citrus aurantifolia) and Sweet lemon (Citrus limetta) budded on sour orange growing in a clay soil in a private farm in Rasheed, Behera Governorate, Egypt. The obtained data indicated that genetic analysis resulted in 137 total amplicons with an average 15.22 and 136 polymorphic amplicons with an average 15.11 and one monomorphic amplicon with an average 0.111 with $100 \%$ for all studied primers except S1 which give $88 \%$ polymorphism with an average $98.76 \%$. High fragments number were observed in Eurkea Lemon cultivar reached 57 fragments band, while the less fragments number was observed in Egyptian lime and sweet lemon cultivars reached 45 fragments band. Genetic similarity among analyzed Citrus cultivars ranged from (0.04) between red kalili and shaery lime to $(0.77 \%)$ between blood orange and white kalili. The genetic distance was 9.85 between Kalili orange and Shaery lime as well as Red Kalili and Shaery lime. In addition, it was 9.75 between Red Kalili and Eurkea Lemon and the same between Balady orange and Shaery lime. Nine RAPD primers generate 44 markers (39 positive and 5 negative markers) ranged from 110 to $1400 \mathrm{bp}$ as well as, MDH gene expression ratio showed that the expression ratio was greater in Eurkea lemon (3.73) and shaery lime (3.88) as it was 2.56 in Red kalili and 2.38 in Egyptian lime. Results of leaves SDS-protein revealed a total number of 11 bands with molecular weight (MW) ranging from a bout 31.8 to $96.3 \mathrm{~K} \mathrm{Da}$. In addition, analysis of data showed four common band (monomorphic 33.4,40.6,58.7 and 92.4 KDa) while, the remaining seven bands were polymorphic with 31.4,36.0,44.3,66.3,81.2,89.6 and 96.3 K Da. Also, results indicated that, Sweet lemon and Balady orange gave the highest bands numbers (9) whereas Eurkea Lemon gave the lowest numbers (5).
\end{abstract}

Keywords: Sweet orange, lemon, lime cultivars, genetic comparisons.

\section{Introduction}

Genetic differences present among Citrus species as of normal bud changes, extensively sexual compatibility between Citrus genus and apomixes associated genera and the long history of cultivation and the wide world dispersal Scora, (1988). Phylogeny and classification as results from molecular marker technologies helped to explain some of these relations. A variation of DNA markers is accessible and used to study the classification of Citrus genus and phylogenetic relations within Citrus and with related genera. Several of these markers are based on molecular hybridization Federici et al., (1998) and Yamamoto et al. (1993) and others are based on Polymerase Chain Reaction (PCR) technique Nicolosi et al., (2000), Breto et al., (2001) and Gulsen et al., (2001).

Malate dehydrogenase is considered of dehydrogenases group, which comprise a gene family of NAD(P) + dependent preserved enzymes that are universally found in plants, animals, fungi and bacteria (Minarik et al., 2002). Malate is inner metabolite that is an important intermediate of the tricarboxylic acid cycle and is essential for cellular metabolism (Fernie and Martinoia, 2009). Furthermore, several MDH gene as a specific primers have been identified in a number of plants, Longo and Scandalios (1969) on maize, Tomaz et al., (2010) on Arabidopsis Yao et al., (2011) on apples and Wang et al., (2015) on cotton. Practical studies reported that MDHs were concerned in the growth and development of plant cells and played an important role in various plant stress responses, like leaf respiration (Tomaz et al., 2010), embryo growth (Beeler et al., 2014) and tolerance to salt stress and cold (Yao et al., 2011). The analysis of transgenic with varied malate metabolisms and the

Corresponding Author: Hala M. El-Khayat, Horticulture Research Institute, Egypt.

E-mail:elkhayat_h_m66@yahoo.com 
recent discovery of different malate protein channels in number of plant tissues have shed new light on its broader value for cellular functions (Faske et al., 1997).

Mitochondrial MDHs perhaps occur as a multifaceted with fumarase and citrate synthase. The source for compound creation is based on the detail that the typical free energy for the MDH catalyzed response is unfavorable in the way of the process of the citric acid cycle. Under ordinary conditions, the MDH reaction is favored in the direction of malate formation. It is believed that the formation of a citric acid cycle enzyme complex drives the cycle in the path of oxaloacetate creation by enabling the transmission of oxaloacetate from MDH to citrate synthase (Beeckmans and Kanarek 1981; Robinson et al., 1987).

The current discovery of special malate protein channels in a lot of plant tissues and transgenic analyze of varied malate metabolisms have shed new light on malate broader importance for cellular functions (Faske et al., 1997). Malate dehydrogenase considered one of dehydrogenases collection, which include a gene family of $\mathrm{NAD}(\mathrm{P})+$ dependent conserved enzymes that are commonly found in fungi, plants, animals and bacteria (Minarik et al., 2002). Malate is an internal metabolite that is an important intermediate of the tricarboxylic acid cycle and necessary for cellular metabolism (Fernie and Martinoia, 2009). Moreover, MDH gene as specific primers have been identified in a number of plants, including Arabidopsis (Tomaz et al., 2010), Maize (Longo and Scandalios, 1969), Apples (Yao et al., 2011) and cotton (Wang et al., 2015). Also, Tomaz et al., (2010) in purposeful studies revealed that MDHs were disturbed in the growth and development of plant cells and did a vital role in different plant stress responses, such as, salt stress, tolerance to cold and leaf respiration (Yao et al., 2011).

A real-time polymerase chain reaction, also known as measurable polymerase chain response, is a laboratory method of molecular environmental science created on the polymerase chain reaction. It monitors the amplification of a beleaguered DNA molecule during the PCR, i.e. in real-time, and not at its end, as in conservative PCR. Gene-expression examination is progressively significant in many arenas of biological research. Sympathetic patterns of spoken genes is predictable to deliver insight into complex regulatory networks and will most probably lead to the identification of genes relevant to new biological processes, or implicated in disease (Schena et al., 1995).

Quantitative real-time reverse transcription polymerase chain reaction (qPCR) has become the preferred method for studying low-abundant mRNA expression. Appropriate application of qPCR in such studies requires the use of reference gene(s) as an internal control in order to normalize the mRNA levels between different samples for an exact comparison of gene expression levels. Expression of the reference gene should be independent from development stage, cell/tissue types, treatments and environmental conditions. Recognizing the importance of reference gene (s) in normalization of qPCR data, various reference genes have been evaluated for stable expression under specific conditions in various organisms. In plants, only a few of them have been investigated, and very few reports about such reference genes in citrus.

Seed protein electrophoresis as well as leaf proteins provide valuable evidence for taxonomic and evolutionary relationships of plant species (Yates et al., 1990)

The present work was under taken in order to differentiate four sweet orange (Citrus sinensis L. Osbeck) cvs Balady, Blood, White Kalili and Red Kalili and four lemon and lime cultivars Eurkea lemon (Citrus limon) and Shaery Lime, Egyptian lime (Citrus aurantifolia), Sweet lemon (Citrus limetta), budded on sour orange s growing in clay soil in respect of tree growth, tree yield, fruit quality leaf chlorophyll leaf carbohydrate and mineral content and some genetic characteristics were studied by El-khayat (2019) and this is the rest of this work.

\section{Materials and Methods}

This investigation was conducted in 2016 season at a private farm in Rasheed Behera, Governorate Egypt to study the Genetic diversity variation of four sweet orange (Citrus sinensis L. Osbeck) trees cvs: Balady, Blood orange (Ahmar bedamo), Khalili, and red Khalili (Khalili ahmar) budded on sour orange four lemon and lime cvs, Eurkea and sheary Lemon( Citrus limon), Egyptian lime (Citrus aurantifolia) and Sweet emon (Citrus limetta) budded on sour orange growing in clay soil. 
Figures:
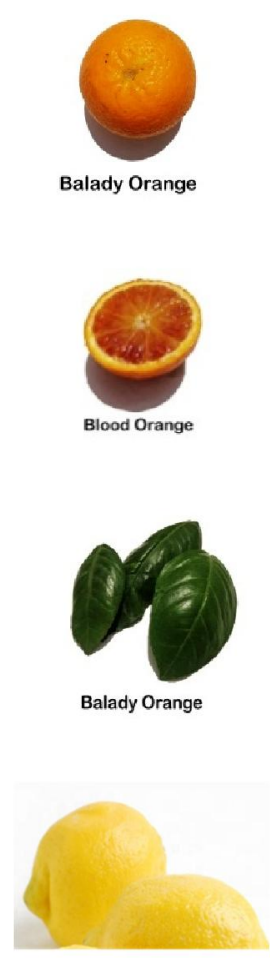

Eurea temon
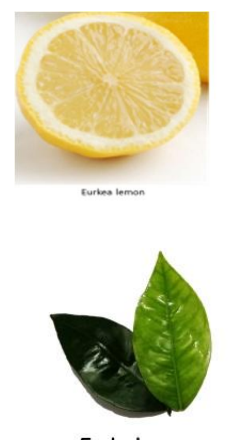

Eurka Lemon

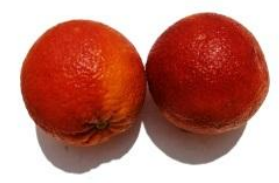

Blood Orange
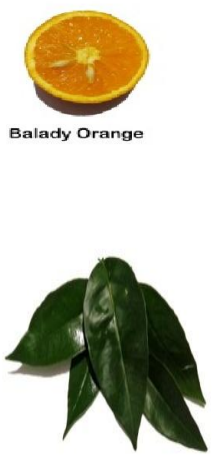

Blood Orange
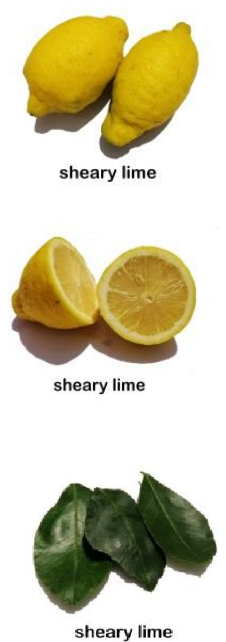

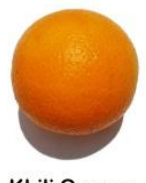

Khili Orange
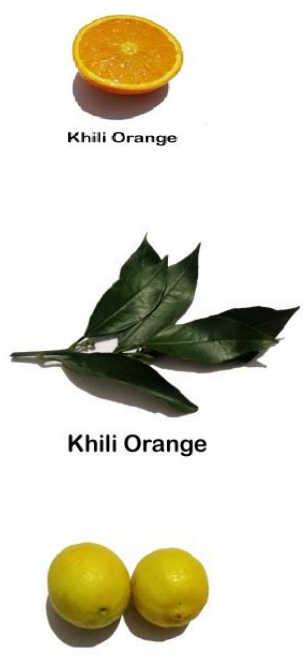

Egyption Lime

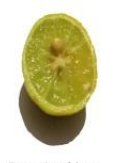

Egyption Lime

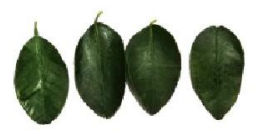

Egyption Lime
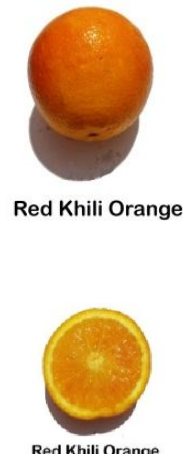

Red Khili Orange

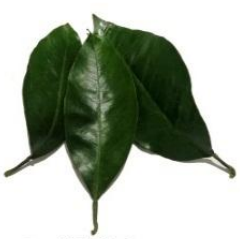

Red Khili Orange
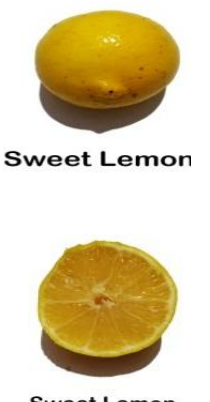

Sweet Lemon

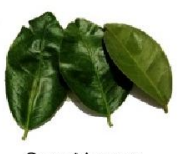

Sweet Lemon

\section{Extraction of DNA from plant leaves:}

The recent small leaves tissues of four sweet orange and four lemon and lime cvs were grounded to a fine powder in liquid nitrogen and the DNA were isolated using I-Genomic Plant DNA Extraction Mini Kit (INRTON) according to manufacturer's instructions.

\section{RAPD-PCR and Electrophoresis:}

Isolation of total genomic DNA for random amplified polymorphic DNA (RAPD) was carried out according to Dellaporta et al. (1983) as follow: a sample of recently small leaves from each variety were grounded to a fine powder in liquid nitrogen and the DNA was isolated from each sample using I- Genomic Plant DNA Extraction Mini Kit (INRTON) according to manufacturer's instructions. In addition, eight random primers were used to differentiate fingerprint of the isolated DNA of each variety and primers sequences are illustrated in Table (5). The PCR reaction mixture was carried out in a final volume of $25 \mu \mathrm{L}(8.8 \mu \mathrm{L}$ Sterile Milli Q water; $5 \mu \mathrm{L}$ of $5 \times$ xCR reaction green buffer; $2.5 \mu \mathrm{L}$ of $50 \mathrm{mM}-\mathrm{MgCl} 2 ; 2.5 \mu \mathrm{L}$ of $25 \mathrm{mM}$-dNTPs; $5 \mu \mathrm{L}(50 \mathrm{pmol} / \mu \mathrm{L})$ of each arbitrary primers; $0.2(5 \mathrm{U} / \mu \mathrm{L})$ Taq polymerase and $1 \mu \mathrm{L}$ of DNA). The applied PCR program was performed as follow : initial denaturation at $95^{\circ} \mathrm{C}$ for 5 min.; 40 cycles at $95^{\circ} \mathrm{C}$ for 1 min.; annealing ranged at $28-30^{\circ} \mathrm{C}$ for $1 \mathrm{~min}$ and extension at $72^{\circ} \mathrm{C}$ for $1 \mathrm{~min}$. A final extension step at $72^{\circ} \mathrm{C}$ for $10 \mathrm{~min}$, the 
reaction conditions and the mixtures used were according to Ahmed et al. (2005). PCR products were separated on agarose gel electrophoresis using $2 \%(\mathrm{w} / \mathrm{v})$ agarose in $0.5 \mathrm{x}$ TBE buffer. The size of each band was estimated by using DNA molecular weight marker. Finally, the gel was photographed by using gel documentation system.

\section{RAPD analysis and phylogenetic relationships:}

Bands of DNA fragment were scored manually for all the samples studied as present (1) and absent (0). Level of marker polymorphism according to the various molecular techniques and data were analyzed with program STATISTICA ${ }^{(\mathrm{R})}$ software version 5. Dendogram displaying relationships of eight citrus cultivars was constructed using the unweighted pair group's method arithmetic average (UPGMA). Similarity was calculated according to Nei and lei (1979). Dendrogram were constructed using genetic distance according to Evritt (1993) and Eisen et al. (1998).

\section{PCR amplification of malate dehydrogenase (MDH) gene and phylogenetic tree:}

A pair of degenerate oligonucleotide primers were corresponding to forward; 5 GCTCCTGTGGAAGAGACCC- ' 3 and reverse; 5'-TCCAGAGATGACCAAAC-3' were used to amplify the DNA fragments of MDH gene as a specific primer of citrus cultivars (Ramadugu et al., 2013). In addition, PCR reaction mixture was carried out in a final volume of $25 \mu$, consisting of $1 \mu \mathrm{L}$ DNA template, $5 \mu \mathrm{L}$ of $5 \mathrm{x}$ buffer, $2.5 \mu \mathrm{l} \mathrm{MgCl}_{2}, 2.5 \mu \mathrm{L}$ dNTPs, $1 \mu$ Lof each primer $(10 \mathrm{pmol} / \mu \mathrm{L}), 1 \mathrm{U}$ Taq DNA polymerase (Promega, USA) and up to volume nuclease-free water. PCR was programed with initial denaturation at $95^{\circ} \mathrm{C}$ for $5 \mathrm{~min}$ and 30 cycles at $95^{\circ} \mathrm{C}$ for $1 \mathrm{~min}$.; annealing at $55^{\circ} \mathrm{C}$ for 1 min and extension at $72^{\circ} \mathrm{C}$ for $1 \mathrm{~min}$, with final extension step at $72^{\circ} \mathrm{C}$ for $10 \mathrm{~min}$. Finally, $5 \mu 1$ of each PCR product was separated on $2 \%$ agarose gel electrophoresis for $1.5 \mathrm{~h}$. at $90 \mathrm{v}$. After staining with $0.5 \mu \mathrm{g} / \mathrm{cm}^{3}$ ethidium bromide, gel was photographed using gel documentation system, and DNA length was estimated via Ladder DNA marker. The phylogenetic tree was analyzed and generated based on neighbor-joining statistic method.

\section{Total RNA Isolation:}

Total mRNA was isolated from $0.250 \mathrm{~g}$ leaves of the studied orange cvs using Tripure total RNA extraction reagent, according to manufacturer's instructions. The purified RNA was quantitated spectrophotometrically, and analyzed on $1 \%$ agarose gel.

\section{Reverse transcription of RNA (RT-PCR):}

Reverse transcription reactions were performed using oligo dT primer. A $20 \mu \mathrm{l}$ reaction mixture contained $2.5 \mu \mathrm{l} 5 \mathrm{X}$ buffer, $2.5 \mu \mathrm{lgCl}_{2}, 10$ as primer ( $\left.10 \mathrm{pml} / \mu \mathrm{l}\right), 2.5 \mu \mathrm{l} 2.5 \mathrm{mM}$ dNTPs, $4 \mu \mathrm{l}$ from oligo (dT), $0.2 \mu \mathrm{l}(5 \mathrm{Unit} / \mu \mathrm{l})$ reverse transcriptase (Promega, Germany) and $2.5 \mu \mathrm{l}$ RNA. RT-PCR amplification was performed in a thermal cycler PCR, programmed at $42^{\circ} \mathrm{C}$ for $1 \mathrm{~h}$ and $72^{\circ} \mathrm{C}$ for 20 $\min$.

\section{mRNA expression of MDH genes:}

The primer sequences used in qRT-PCR are given in Table (1). Primers specific to $\beta$-Actin (internal reference control gene) and malate dehydrogenase gene (MDH) using SYBR GREEN method, qPCR was performed in a total reaction volume of $25 \mu$ l containing $12.5 \mu \mathrm{l}$ of $1 \times \mathrm{SYBR}$ GREEN PCR mix, $1.5 \mu \mathrm{l}$ sets of each primer, $2.5 \mu \mathrm{l}$ cDNA templates, and $7 \mu 1$ Rnase free dd water. 3step amplification protocol RT-qPCR was performed for 40 cycles of $95{ }^{\circ} \mathrm{C}$ for $15 \mathrm{~s}, 60^{\circ} \mathrm{C}$ for $30 \mathrm{~s}$ and $72{ }^{\circ} \mathrm{C}$ for $30 \mathrm{~s}$. The $\mathrm{CT}$ of each sample was used to calculate $\Delta \mathrm{CT}$ values (target gene $\mathrm{CT}$ subtracted from $\beta$-Actin gene CT). The relative gene expression was determined using the $2^{-\Delta \Delta \mathrm{Ct}}$ method according to Togawa et al. (2008).

'Table 1: Nucleotide sequences of the primers used in qRT-PCR

\begin{tabular}{lccl}
\hline Gene name & Sides & Primer sequence (5'-3') & Annealing temp. \\
\hline \multirow{2}{*}{$\boldsymbol{\beta}$-Actin } & $\mathrm{F}$ & 5'-ATCTGCTGGAAGGTGCTGAG -3' $^{\prime}$ & \\
\multirow{2}{*}{ MDH } & $\mathrm{R}$ & 5'-CCAAGCAGCATGAAGATCAA -3' $^{\prime}$ & \\
& $\mathrm{F}$ & 5'-GCTCCAGAGATGACCAAAC-3' & $60^{\circ} \mathrm{C}$ \\
\hline
\end{tabular}




\section{Protein extraction:}

Total soluble protein were extracted by grounding $0.25 \mathrm{~g}$ of each sample in $0.9 \mathrm{ml}$ extraction buffer $(10 \mathrm{ml} 0.5$ MTris $\mathrm{pH} 6.8,16 \mathrm{ml} 10 \% \mathrm{SDS}, 30 \mathrm{ml}$ D.W) with shaking thoroughly. The extracts were transferred to eppendorf tubes and centrifuged for $10 \mathrm{~min}$. at 10000rpm under cooling. Supernatant were transferred by fresh tubes and used for SDS-PAGE analysis and extraction of isozymes was used as described by Jonathan et al. (1990).

\section{Protein related index:}

Fractionation electrophoresis was performed under identical conditions on sodium dedocyl sulphate polyacrylamide gel (SDS-PAGE) $(12 \% \mathrm{~W} / \mathrm{V})$ vertical slab using BIORAD Techware $1.5 \mathrm{~mm}$ according to the method of Laemmli (1970) as modified by Studier (1973). The molecular weights of proteins were estimated relative to marker, a wide range molecular weight protein (Fermentas com). Gels were photographed scanned, analyzed using Gel Doc (VILBER LOURMAT) system to capture the image and to calculate band intensities.

\section{Results and Discussion}

Random amplified polymorphic for DNA (RAPD) molecular marker was used to separate and determine genetic diversity and phylogenetic connotation of four sweet orange (Citrus sinensis L. Osbeck) trees cvs; Baladi orange, Blood orange, Kalili orange and Red Kalili orange and lemon and lime trees cvs; Eurkea Lemon (Citrus limon), Shaery lime and Egyptian lime (Citrus aurantifolia) and Sweet lemon (Citrus limetta cultivars budded on sour orange.
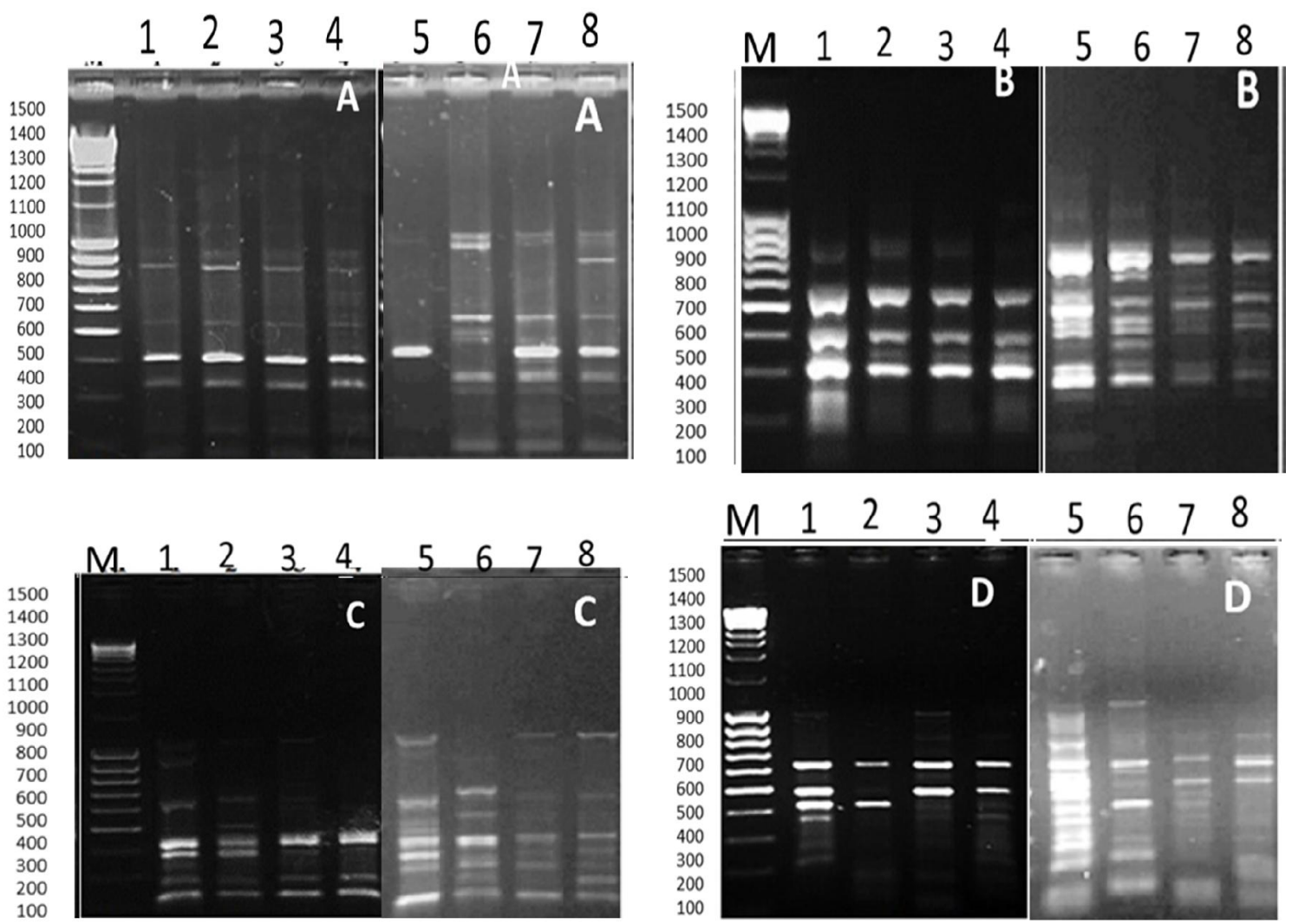

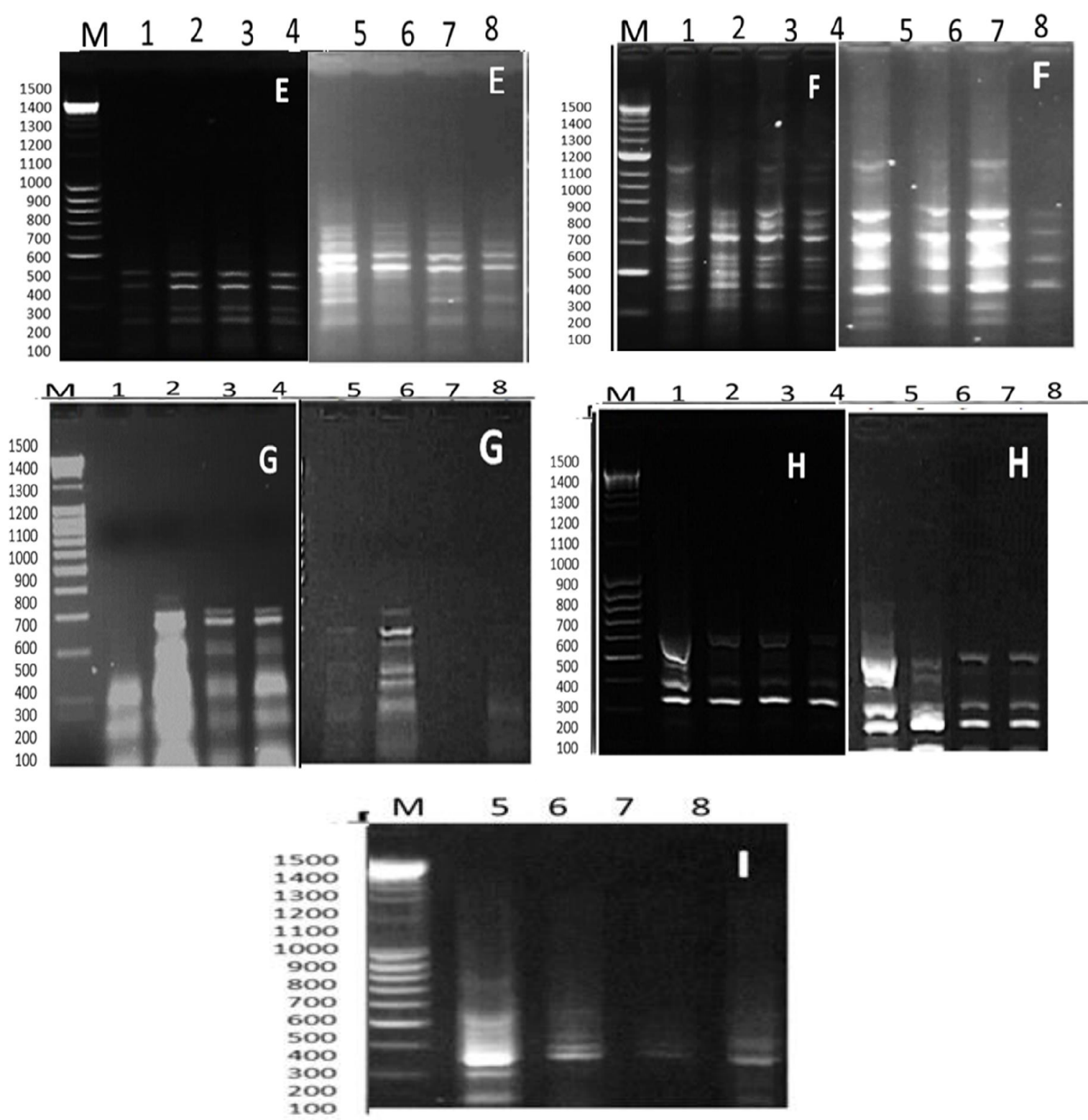

Fig. 1: 2\% Agarose gel electrophoresis of RAPD-PCR using primer's (A):RAPD2; (B):RAPD4; (C):RAPD6; (D):RAPD8; (E):RAPD10; (F):Es10A26; (G):P1; (H):S1; (I):S2; M, $1.5 \mathrm{Kbp}$ DNA marker, Lane 1 Baladi orange; Lane 2 Blood orange; Lane 3 Kalili orange,; Lane4 Red Kaliliorange, Lane 5Eurkea Lemon,; Lane 6Sheay lime; Lane 7Egyptian lime,; Lane 8Sweet lemon, respectively.

Using nine primers showed regularly different banding patterns with reproducible polymorphic bands that variable in size and number. 399 bands with size $30-1400 \mathrm{bp}$ and led to 137 total amplicons with an average 15.22 and 136 polymorphic amplicons with an average15.11 and one monomorphic amplicon with an average 0.111 with $100 \%$ for all studied primers except S1 which give $88 \%$ polymorphism with an average $98.76 \%$.

Comparing sweet orange, lemon and lime cultivars shown from RAPD marker data revealed that high fragments number were observed in Eurkea Lemon cultivar reached 57 fragments band, while the less fragments number was observed in Egyptian lime and sweet lemon cultivars reached 45 fragments band (Table 3). 
Table 2: Nucleotide sequences of the primers, total number of amplicons, monomorphic amplicons, polymorphic amplicons and polymorphism percentages as revealed by nine random primers among the sweet orange, lemon and lime accessions collected from Rasheed region.

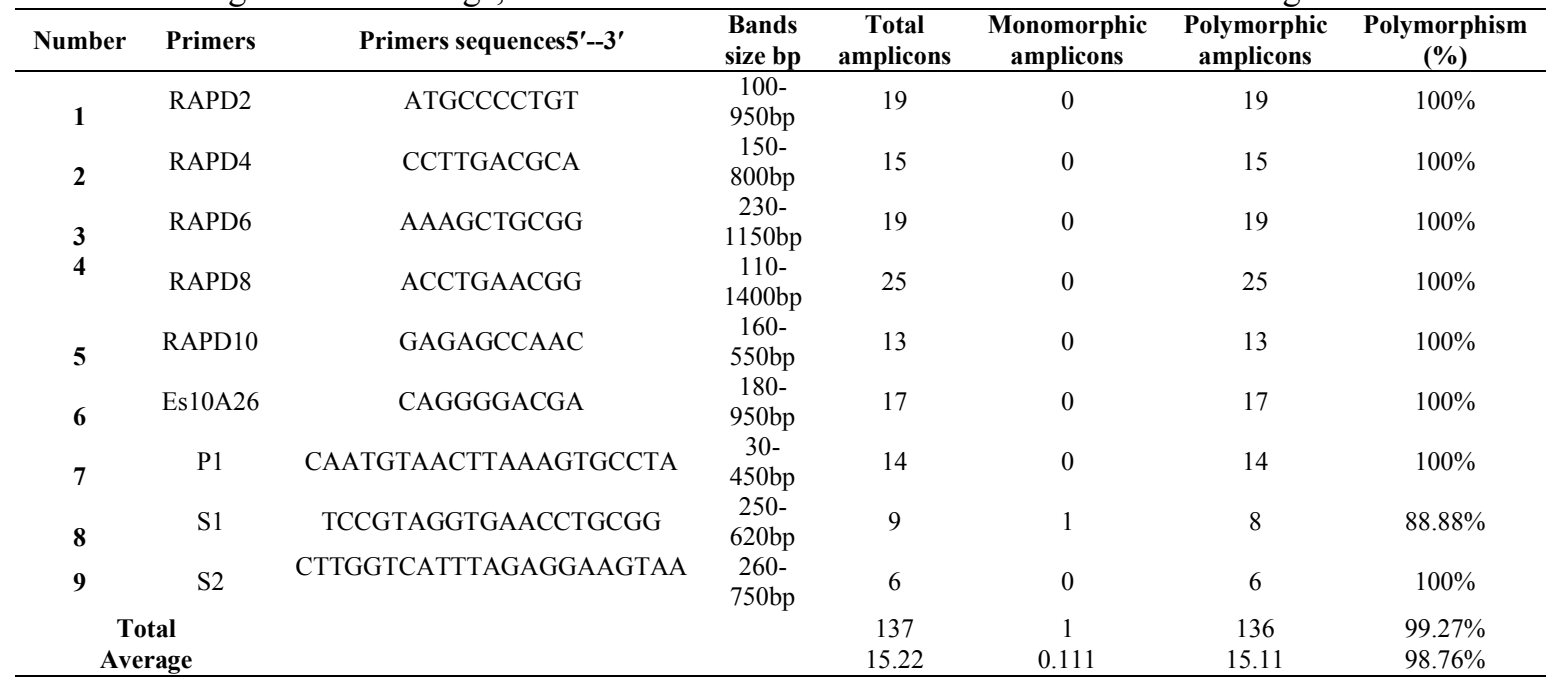

Table 3: Sweet orange lemon and lime cultivars fragments numbers RAPD markers

\begin{tabular}{lc}
\hline Genotype(cultivars) & Number of total Fragment \\
\hline Baladi orange & 48 \\
Blood orange & 47 \\
Khalili orange & 53 \\
Red Khalili orange & 48 \\
Eurkea Lemon & 57 \\
Shaery Lime & 56 \\
Egyptian lime & 45 \\
Sweet lemon & 45 \\
\hline
\end{tabular}

\section{Phylogenetic Analysis:}

To determine the genetic relations among 8 citrus cultivars, the results based on RAPD data were used for estimate the genetic similarity between the analyzed citrus cultivars. These genetic similarity matrices were then used in the cluster analysis to produce a dendogram using in the cluster analysis UPGMA analysis. Similarity matrix (data dose not presented) indicated that genetic similarity among analyzed Citrus cultivars ranged from $(0.04)$ between red kalili and shaery lime to $(0.77 \%)$ between blood orange and white kalili .Similarity tree based on RAPD (Fig. 2 and table 4$)$ molecular phylogenic dendrogram generated two main clusters, the first main cluster contained sweet orange cultivars and split to two sub-clusters clusters (A and B): cluster (A) consisted of Blood orange and Khalili orange at similarity value 0.77 , while the second (B)contained Balady orange and Red Khalili in the other at similarity value 0.73 , while the second main cluster consisted of lemon and lime cultivars and split to two sub-clusters, the first sub-cluster consisted of the first (C) consisted of Shaery lime the other is the major cluster D contained two sub clusters (D1 \& D2), subcluster D1 expressed Eueka lemon whereas, sub -cluster D2 includes two species on the same line it is sweet lemon and Egyptian lime with similarity value 0.64 .

The similarity value struck $0.07,0.05,0.08$ and 0.11 between balady orange and Eurkea Lemon, Shaery lime, Egyptian lime and Sweet lemon, respectively .Also it proved to be 0.07, 0.06, 0.07 and 0.11 between blood orange and Eurkea Lemon, Shaery lime, Egyptian lime and Sweet lemon, respectively. Moreover, similarity value found to be $0.09,0.06,0.07$ and 0.1 between Kalili and Eurkea Lemon, Shaery lime, Egyptian lime and Sweet lemon, respectively whereas similarity value was 0.06, 0.04, 0.07 and 0.09 between Red Kalili and cultivars Eurkea emon, Shaery lime, Egyptian lime and Sweet lemon, respectively. Similar results were reported by Al Anbari et al. (2014) they classified citrus genotype into two mean groups the first contain the citron (Citrus medica) and citron hybrids (lemon and lime) and the second is separated into three sub groups; A 
consist of sweet orange (Citrus sinensis), sour orange (Citrus aurantium) and grapefruit (Citrus paradise), B contains of the mandarins (Citrus reticulate) and $\mathrm{C}$ is the pummelo (Citrus grandis). They also reported that the RAPD-based association was reliable with previous studied established on other types of molecular markers. In addition they found that the sweet orange (Citrus sinensis) group has high similarity coefficient value of about 0.82 this indicate their relationship. Moreover, Bayer $e t$ al. (2009) reported that citrus contained two lineages, the largely contained primarily wild species from new mandarin group, the lime group and pummello group as well as El-Mouei et al. (2011a) concluded that RAPD and SSR markers can identify enough polymorphism to differentiate and characterization. Luro et al. (2011) organized 87 citrus varieties into two main groups .The first group include mandarins, sour orange sweet orange, pummlo and grapefruit; and the second group contained citron, lemons and limes and lemon hybrids. Recently. Uzun et al. (2011) found that genetic similarity among lemons and rough lemon $C$. volkameriana group was 0.80 and rough lemons and $C$. volkameriana were directly related. Moreover, they reported that there was a low level of polymorphism among most of lemons resulting via clonal selection whereas higher genetic diversity was found in lemons which had hybrid origin. Also, Ahamed (2012) found that 12 Citrus accessions generated two main sub-clusters (I and II). Sub-cluster (I) comprised of four common sweet orange cultivars which in turn were divided into two groups: Florida and Shamoty in the first group and Fsido and Valencia in the second one. Furthermore, Hamza (2013) indicated that the phylogenetic analysis showed that the genetic similarity ranged from 0.626 to 0.879 and there was relationship between the nineteen analyzed Citrus cultivars. Also, Sour orange, Rangpur lime, Volkamer lemon and Macrophylla were so closed and involved in the same cluster. Finally, it could be illustrated that the used RAPD molecular markers are effective in will power of partial genome in breeding programs.

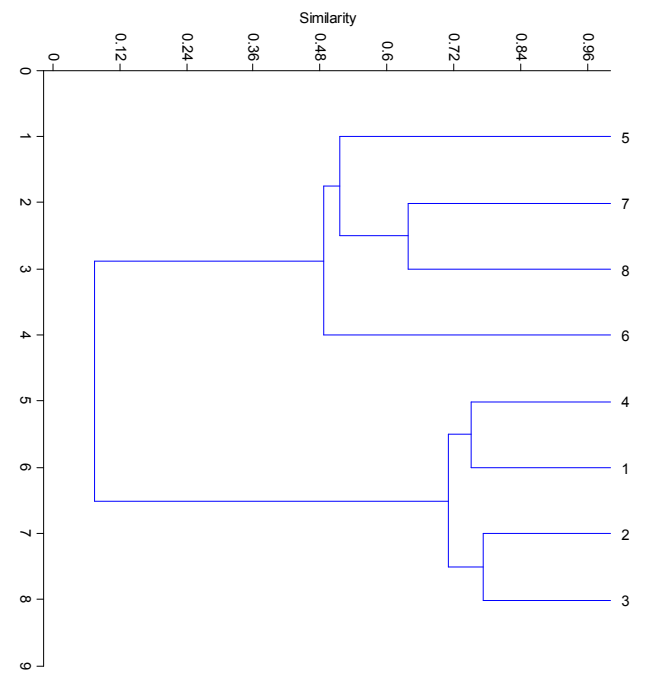

Fig 2: The phylogenetic tree constructed on the basis on RAPD profile with nine primers using the DNA of thefour sweet orange and four lemon and lime cultivars.

Table 4: Similarity value of Baladi orange, Blood orange, Kalili orange, and Red Kalili orange(Citrus sinensis L. Osbeck) and Eurkea Lemon (Citrus limon), Sheay lime, Egyptian lime (Citrusaurantifolia) and Sweet lemon (Citrus limetta) cultivars budded on sour orange.

\begin{tabular}{lllllllll}
\hline & $\mathbf{1}$ & $\mathbf{2}$ & $\mathbf{3}$ & $\mathbf{4}$ & $\mathbf{5}$ & $\mathbf{6}$ & $\mathbf{7}$ & $\mathbf{8}$ \\
\hline $\mathbf{1}$ & 1.00 & & & & & & & \\
$\mathbf{2}$ & 0.67 & 1.00 & & & & & & \\
$\mathbf{3}$ & 0.73 & 0.77 & 1.00 & & & & & \\
$\mathbf{4}$ & 0.75 & 0.67 & 0.76 & 1.00 & & & & \\
$\mathbf{5}$ & 0.07 & 0.07 & 0.09 & 0.06 & 1.00 & & & \\
$\mathbf{6}$ & 0.05 & 0.06 & 0.06 & 0.04 & 0.46 & 1.00 & & \\
$\mathbf{7}$ & 0.08 & 0.07 & 0.08 & 0.07 & 0.49 & 0.46 & 1.00 & \\
$\mathbf{8}$ & 0.11 & 0.11 & 0.10 & 0.09 & 0.54 & 0.53 & 0.64 & 1.00 \\
\hline
\end{tabular}




\section{Genetic distance:}

The genetic distance struck 9.64 between Balady orange, Kalili orange and Eurkea Lemon .Also it was 9.59 between Blood orange, Eurkea Lemon and Shaery lime while, it prove to be 9.75 between Red Kalili and Eurkea Lemon Whereas it was 9.75 between Balady orange and Shaery lime. However, it was 9.85 between Kalili orange, Red Kalili and Shaery lime as well as genetic distance value struck 6.48 between Eurkea Lemon and Shaery lime. Also, it was 8.94 between Balady orange and Egyptian lime and 9 between Blood orange and Egyptian lime. Moreover it prove to be 9.17between Egyptian lime and Kalili orange and 9.06 between Egyptian lime and Red Kalili. Also ,it was found to be 5.92 between Eurkea Lemon and Egyptian lime and 6.08 between Egyptian lime and Shaery lime as well as it was 8.72 between Balady orange and Sweet lemon and 8.66 between Blood orange and Sweet lemon. The genetic distance struck 8.94 between Kalili orange and Sweet lemon, however it was 8.83 between Red Kalili and Sweet lemon and 5.57 between Eurkea Lemon and Sweet lemon as well as 5.57 between Shaery lime and Sweet lemon and finally it was 4.47 between Egyptian lime and Sweet lemon. These results are partially in line with those reported by Ahamed (2012 ) who revealed that 12 studied citrus cultivars separated at the highest distance (0.92) and lowest dissimilation distance (0.82). Also, Hamza (2013) studied the genetic distance for 19 Citrus cultivars and they were showed by phylogenetic analysis.

Table 5: Genetic distance value of Baladi orange ,Blood orange, Kalili orange, and Red Kalili orange(Citrus sinensis L. Osbeck) and Eurkea Lemon (Citrus limon), Sheay lime ,Egyptian lime (Citrusaurantifolia) and Sweet lemon (Citrus limetta) cultivars budded on sour orange

\begin{tabular}{lllllllll}
\hline \multicolumn{1}{c}{} & $\mathbf{1}$ & $\mathbf{2}$ & $\mathbf{3}$ & $\mathbf{4}$ & $\mathbf{5}$ & $\mathbf{6}$ & $\mathbf{7}$ & $\mathbf{8}$ \\
\hline $\mathbf{1}$ & 0 & & & & & & & \\
$\mathbf{2}$ & 4.3589 & 0 & & & & & & \\
$\mathbf{3}$ & 4 & 3.60555 & 0 & & & & & \\
$\mathbf{4}$ & 3.74166 & 4.3589 & 3.74166 & 0 & & & & \\
$\mathbf{5}$ & 9.64365 & 9.59166 & 9.64365 & 9.74679 & 0 & & & \\
$\mathbf{6}$ & 9.74679 & 9.59166 & 9.84886 & 9.84886 & 6.48074 & 0 & & \\
$\mathbf{7}$ & 8.94427 & 9 & 9.16515 & 9.05539 & 5.91608 & 6.08276 & 0 & \\
$\mathbf{8}$ & 8.7178 & 8.66025 & 8.94427 & 8.83176 & 5.56776 & 5.56776 & 4.47214 & 0 \\
\hline
\end{tabular}

The results presented in table (6) indicated that four genotypes were characterized by nine RAPD markers and generate 44 markers (39 positive and 5 negative markers) ranged from 110 to $1400 \mathrm{bp}$. Among the four genotypes of sweet orange and lemon and lime varieties primer RAPD8 gave the highest total number of positive markers (ten markers) five markers with Eurka lemon weigh $280,320,360,400$ and $470 \mathrm{bp}$ and three positive markers with Sheary lime at 260,450 and $1400 \mathrm{bp}$.Also, one positive markers with Khalili orange at $110 \mathrm{bp}$ and one positive marker (140bp) with Blood orange while RAPD10, Es10A26 and S1 gave the lowest number of positive markers (one) with Sheary lime, Blood orange and Balady orange ( $330 \& 340 \& 470 \mathrm{bp}$ ), respectively . Primers RAPD2 and RAPD4 each had the highest number of negative markers two markers with Red khalili orange at 670 and 700 and Sheary lime at 300 and $480 \mathrm{bp}$ respectively. Whereas primers RAPD8 had the lowest number of negative markers (one) with Sheary lime at $500 \mathrm{bp}$.These results however, indicated that all tested types applied in this study succeeded in showing different molecular marker patterns which can be relied up on in distinguishing among the studied sweet orange cvs genotypes. These findings were in harmony with that obtained and illustrated previously by Dora et al. (2017) in barley.

\section{Amplification of MDH gene as a specific primer, phylogenetic tree and real time:}

In this study, the band of MDH gene as a specific primer approximately was 1000 amplified from sweet orange cultivars leaves Balady orange, Blood orange, Kalili orange and Red Kalili orange cultivar and from lemon and lime cultivars leaves, Eurkea lemon (Citrus limon), Shaery lime and Egyptian lime (Citrus aurantifolia) and Sweet lemon (Citrus limetta) cultivars budded on sour orange fig 3 and 4 . In the same case, other studies were reported that the malate accumulation in yeast, hairy roots in Arabidopsis and cotton were increased by over expression of MDH. In contrast, the orthologue of GaMDH13 i.e., the MdcyMDHin apple (accession no. DQ221207), which making ease 
the transportation of malate into vacuole by generating electrochemical gradient and contributes to cell expansion, whilst suppressor had lower of malate (Yao et al., 2011b). In this respect, Chou and, Shen (2007) revealed that the nucleotide lengths of these MDHs ranged from 771 to $1692 \mathrm{bp}$.

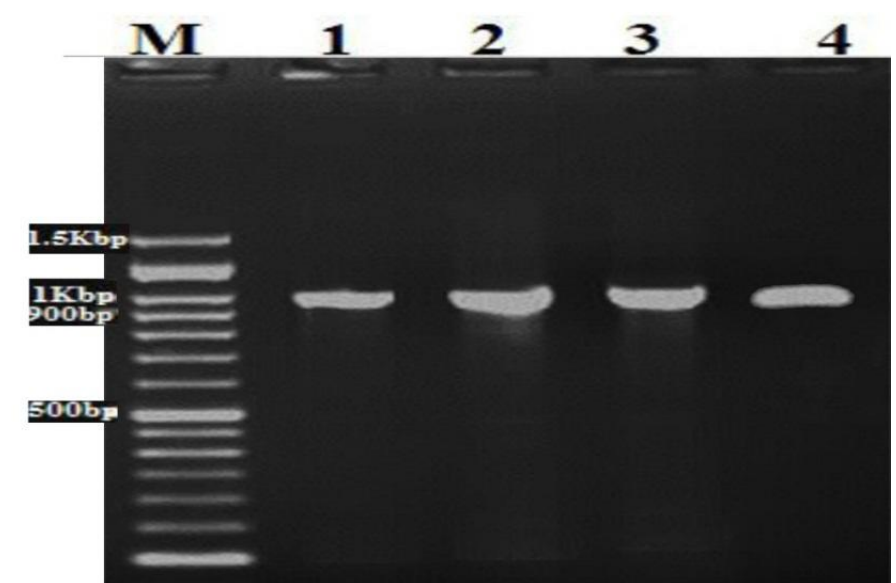

Fig. 3: Specific PCRof MDH gene in orange species :M;1.5kbDNA marker :1Balady Orange;2Blood Orange;3Khalili Orange;4Red Khalili Orange.

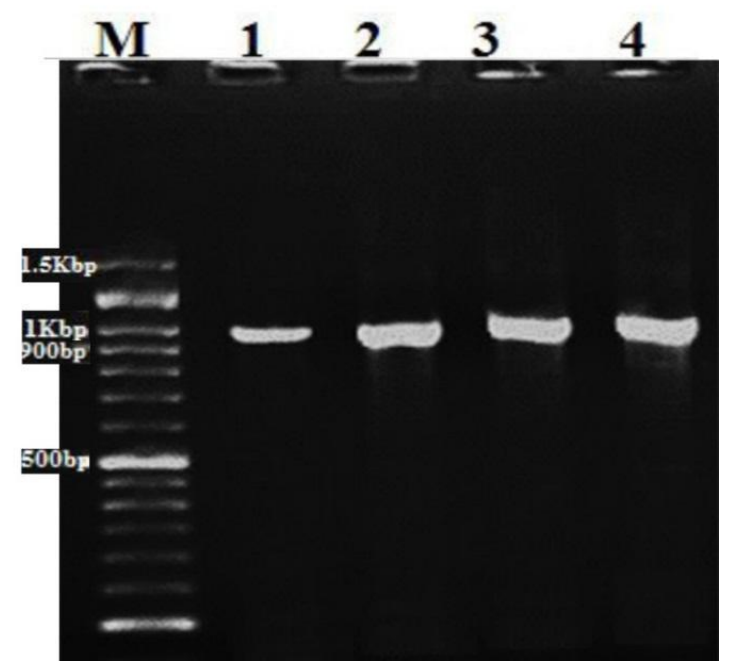

Fig. 4: Specific PCRof MDH gene in lemon and lime species :M;1.5kbDNA marker :1Eureka lemon;2shaery lime ;Egyptian lime;4Sweet lemon.

\section{Real time result:}

Real time quantitative strategy opens up the possibility of studying the biological relevance of small expression differences to identify and determine $\mathrm{MDH}$ genes in studied citrus cultivars tissues and differentiate them. This study evaluated MDH genes from the eight cultivars ,to authenticate the supposed steady expression of a assumed control gene, prior information of consistent measure to standardize this gene in order to remove any nonspecific variation is required. Four different normalization factors were calculated, based on the geometic mean of four genes. qRT-PCRA timecourse qRT-PCR was carried out with mRNA of assess the expression of MDH gene of sweet orange and lemon and lime cultivars. Real time result Table (7) (Figure 5 and 6). 
Table 7: MDH gene expression Ratio of Baladi orange ,Blood orange, Kalili orange, and Red Kalili orange(Citrus sinensis L. Osbeck) and Eurkea Lemon (Citrus limon), Sheay lime, Egyptian lime (Citrus aurantifolia) and Sweet lemon (Citrus limetta) cultivars budded on sour orange .

\begin{tabular}{ll}
\hline Varieties & Expression Ratio (fold) \\
\hline Balady orange & 3.24 \\
Blood Orange & 2.98 \\
Whitekalili & 3.2 \\
Red kalili & 2.56 \\
Eurkea lemom & 3.73 \\
Shaery lime & 3.88 \\
Egyptian lime & 2.38 \\
sweat lemon & 2.86 \\
\hline
\end{tabular}

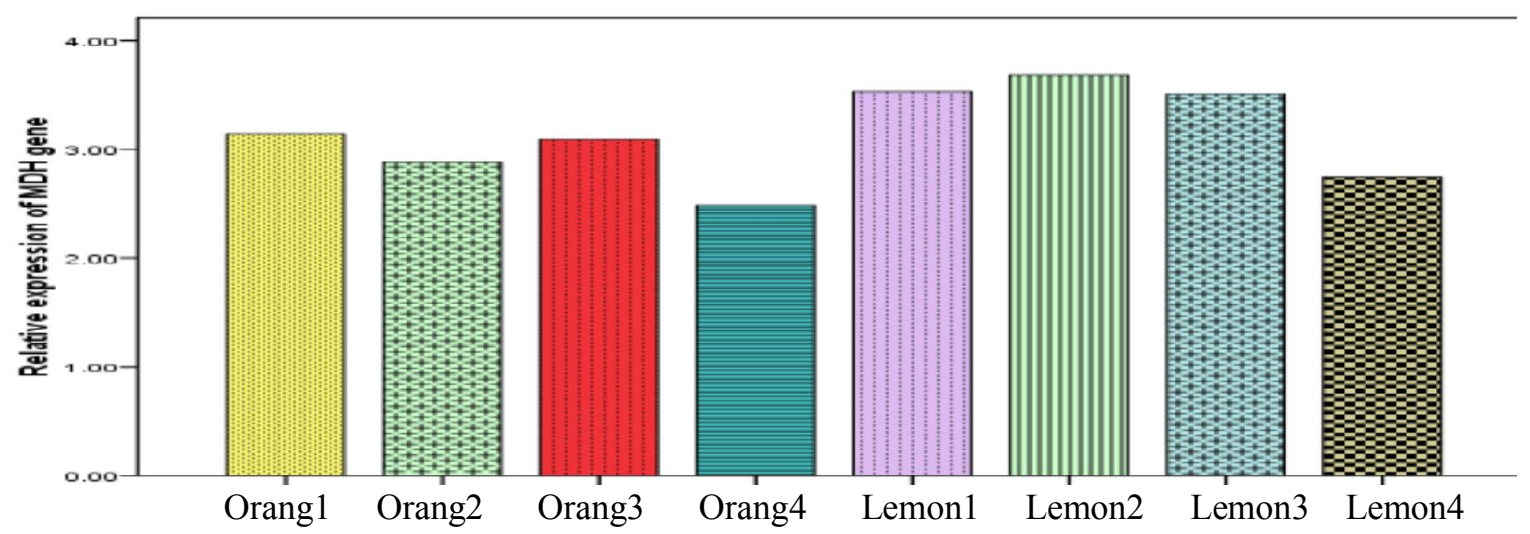

Fig. 5: Relative expression of MDH gene in different citrus species (Baladi orange ,Blood orange , Kalili orange, and Red Kalili orange(Citrus sinensis L. Osbeck) and Eurkea Lemon (Citrus limon), Sheay lime ,Egyptian lime (Citrusaurantifolia) and Sweet lemon (Citrus limetta) cultivars budded on sour orange).

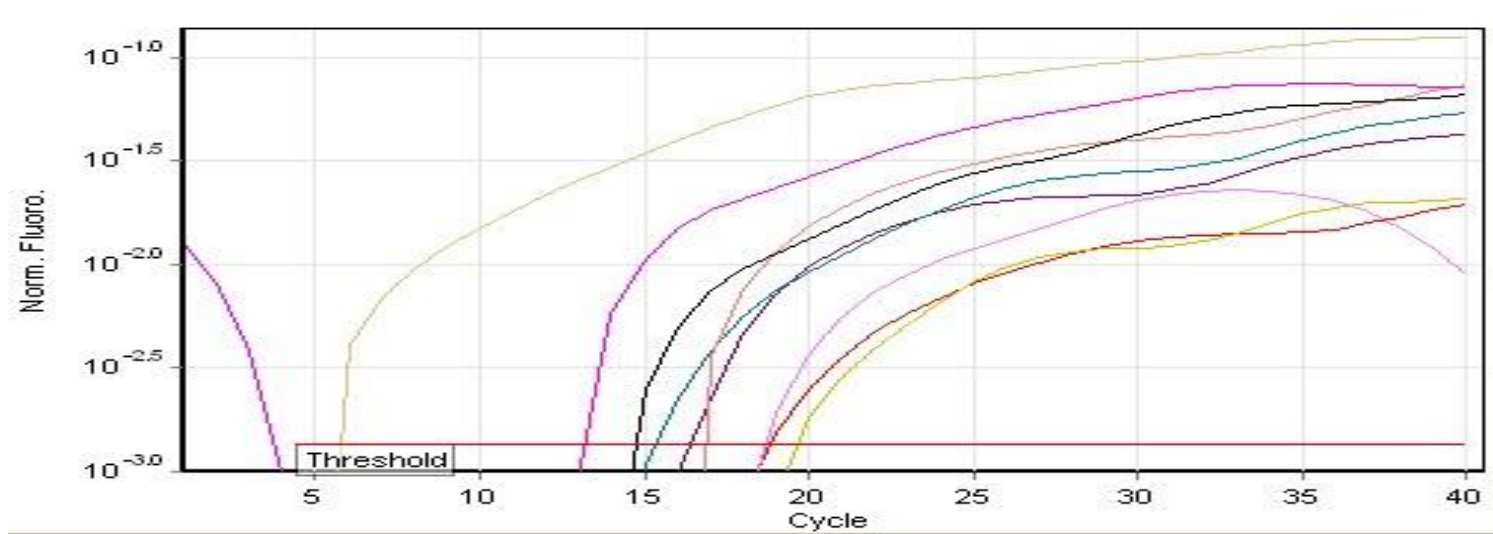

Fig. 6: Sequence features of citrus MDH genes CVS, Baladi orange ,Blood orange, Kalili orange, and Red Kalili orange (Citrus sinensis L. Osbeck) and Eurkea Lemon (Citrus limon), Sheay lime, Egyptian lime (Citrus aurantifolia) and Sweet lemon (Citrus limetta) cultivars budded on sour orange.

The relative expression ratio of MDH gene was greatest in shaery lime and the lowest in Red kalili orange. Also, the data showed that the expression ratio was 3.24 (fold) in Balady orange, 2.98 (fold) for Blood Orange, 3.2 (fold) for White kalili orange and 2.56 (fold) for Red kalili orange. Also, real time result showed that the expression ratio 3.73(fold) in Eurkea lemon, 3.88 (fold) for shaery lime , 2.38 (fold) for Egyptian lime and 2.86 (fold) for sweet lemon. In the same case, other studies reported that the malate accumulation in yeast, hairy roots in Arabidopsis and cotton were increased by over expression of MDH. In another study, Chou and, Shen (2007) revealed that the nucleotide of 
these MDHs molecular weights and theoretical $\mathrm{p} I$ values ranged from $27.26 \mathrm{kDa}$ to $59.78 \mathrm{kDa}$ and 5.27 to 6.37 , respectively. Subcellular localization is crucial for understanding the functional involvement of genes

\section{Protein analysis:}

\section{SDS-Protein electrophoresis in leaves:}

Leaf protein electrophoresis provide valuable evidence for taxonomic and evolutionary relationships of plant species (Yates et al., 1990). The electrophoretic banding pattern of proteins extracted from leaves of the eight trees are shown in Figure (7) and their denstrometric analysis are illustrated in table ( 8 ) the presence and absence of band were assessed with (1) and (0), respectively.

Results of leaves SDS-PAGE revealed a total number of 11 bands with molecular weight (MW) ranging from a bout 31.8 to $96.3 \mathrm{~K} \mathrm{Da}$. Analysis of data showed four common band (monomorphic $33.4,40.6,58.7$ and $92.4 \mathrm{KDa}$ ) while, the remaining seven bands were polymorphic with $31.4,36.0$, 44.3, 66.3, 81.2, 89.6 and 96.3 K Da. Results in figure (1) and table (2) showed that, Sweet lemon and Balady orange gave the highest bands numbers(9) whereas Eurkea Lemon gave the lowest numbers (5).

In this respect, Segent et al., (2004) outlined that protein designated "fintin" had a broad and potent inhibitory effect on the common bean taitmal blight antimicrobial proteins and peptides have been isolated from maize seeds. In grapevine, stebene, phtoalains and PR- proteins accumulate in leaves and berries exposed to biotic and abiotic stresses but in some cases is not known to with extent they contribute to disease resistant or stress reduction, as seen for PR1 (Wielgoss and Kortckamp 2008). The PR proteins encompass different classes or structurally and functionally unrelated proteins that have been grouped into several families according to sequence similarities, (Van loon and Strein, 1999). Giannakis et al., (1998) who established that the two chitinase genes investigated PR-3, PR-4 are constitutively express in Gloire, Grape and may thus represent parts of the performed resistance mechanisms. Recently Kortckamp (2006) demonstrated that expression analysis defense related genes revealed marked differences between the susceptible cultivars belong.

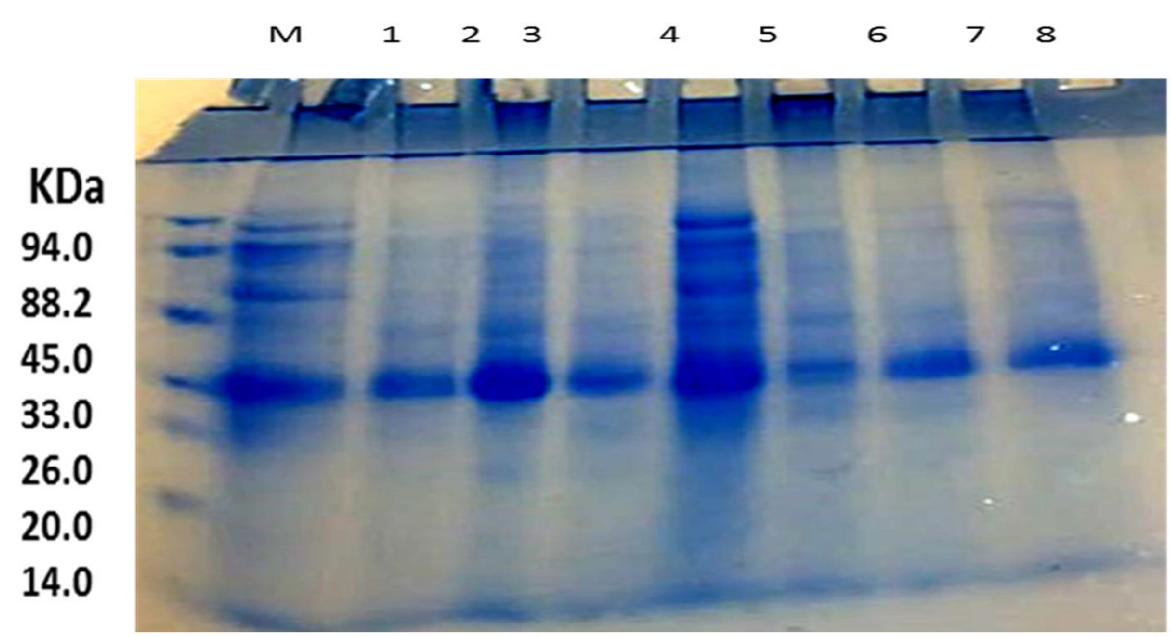

Fig.7 : Protein profile of eight cultivars of citrus: M; 5kb DNA marker: 1, Shaery Lemon; 2, Eurkea Lemon; 3, Sweet lemon; 4, Egyptian lime; 5, Baladyorange; 6, Bloodorange; 7, Red Kaliliorange and 8, Kalili orange. 
Table 8 : Densitometric analysis for SDS leaf proteins the eight citrus cultivars 1, Shaery Lemon; 2, Eurkea Lemon; 3, Sweet lemon; 4, Egyptian lime; 5, Baladyorange; 6, Bloodorange; 7, Red Kaliliorange and 8, Kalili orange.

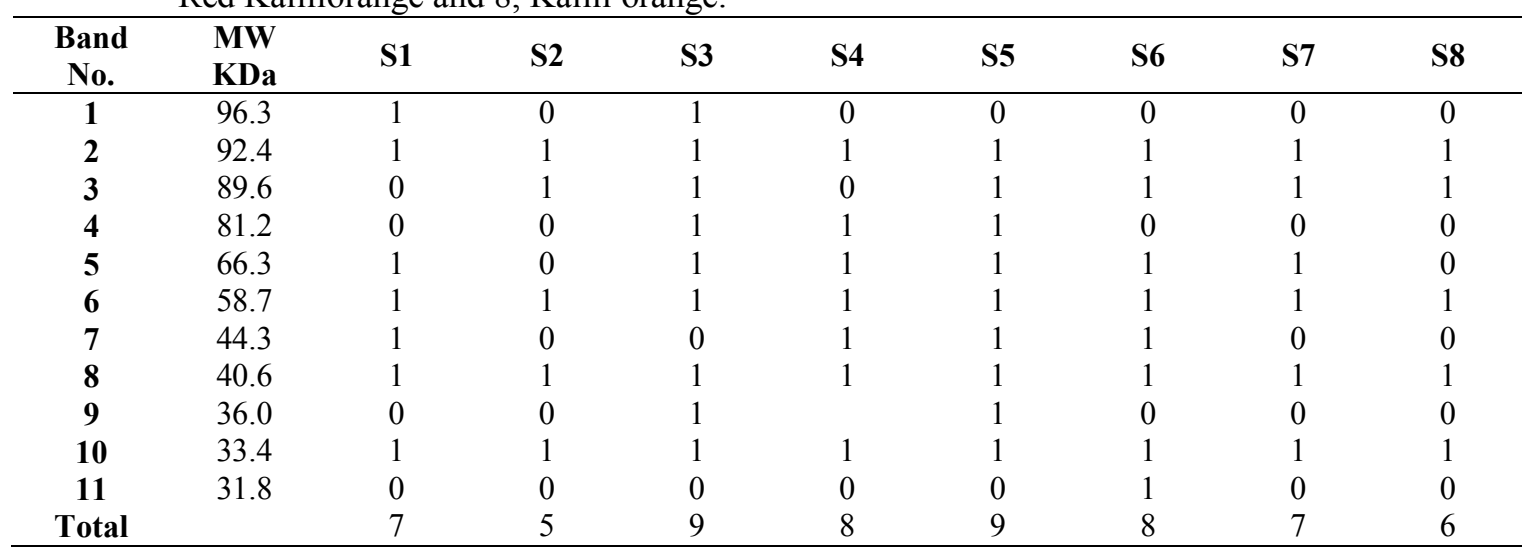

\section{References}

Ahmed, H. F., 2012. Phytohormones content and random amplified polymorphic DNA (RAPD) marker assessment of some Egyptian citrus cultivars. African Journal of Biotechnology 11(91): $15755-15762$.

Ahmed, H.F.S, A.A, Mahmoud, N.M.E. Hamid-Eldin and A. Bhieldin, 2005. Gamma irradiation- and sodium azide induced changes in growth, leaf protein patterns and genomic DNA of two strains of maize under drought stress. Isotope Rad. Res., 37(1):1-17.

AL-Anbari, A.K, N. Kanawappe, A.T. AL-Kazgri, H. AL-Jewari, A.AL-Mashhadani, S. Barusrux, P. Pornpongrungeng. and P. Theerakulpisut ,2014.Genetic diversity of citrus (Rutacea) in Iraq based on Random amplified polymorphic DNA(RAPD) markers. Afr. J. Agri. Res. 9 (11):10121019.

Bayer, R.J., D.J. Mabbertey, C. Morton, C.H. Miller, I.K. Sharma, B.E. Pfeil, R. Hitchcok and S .Sykes, 2009 .A molecular phlogeny of the subfamily(Rutaceae: Aurantioideae) using nine $\mathrm{cp}$ DNA sequences. Am. J. Bot., 96 (3):668-685.

Beeckmans, S.L.K., 1981. Demonstration of physical interactions between consecutive enzymes of the citric acid cycle and of the aspartate-malate shuttle. A study involving fumarase, malate dehydrogenase, citrate synthesis and aspartate aminotransferase. Eur. J. Biochem., 117: 527535.

Beeler, S, H.C. Liu, S. Hung and T. B. Schreier, 2014. Plastidial NAD-Dependent Malate Dehydrogenase Is Critical for Embryo Development and Heterotrophic Metabolism in Arabidopsis. Plant physiology Plant physiology 164 (3).

Breto, M.P., C. Ruiz, J.A. Pin. and M.J. Asins, 2001. The diversification of Citrus clemantina Hort. ex Tan, a vegetatively propagated crop species. Mol. Phylogenet. Evol., 21: 285-293.

Chou, K.C and H.B. Shen, 2007. Recent progress in protein subcellular location prediction. Analytical biochemistry. 370 (1):1 116. doi: 10.1016 /j.ab.2007.07.006 PMID: 17698024.

Dellaporta, SL, J .Wood and J.B. Hicks, 1983. A plant DNA mini preparation: version II. Plant Mol. Biol. Rep. 1:19-21.

Dora, S. A, M. Mansour., A, A. Aboulila and E. Abdelwahab, 2017.Genetic Diversity And Relationships Among Some Barley Genotypes For Net Blotch Disease Resistance Using RAPD, SCOT And SSR Markers. Egypt. J. Genet. Cytol., 46: 139-165.

Eisen, M. B., P .Spellman, P. O. Brown and D. Botstein, 1998. Cluster analysis and display of genome-wide expression patterns. Proceedings of the National Academy of Sciences of the United States of America, 95(25), 14863-14868.

El-Khayat, H. M., 2019 . Horticulture Performance and Genetic Diversity Based on RAPD Markers of Some Sweet Orange Cultivars in Egypt .Middle East Journal of Agriculture Research, 08 (02): 611-623. 
El-Khayat, H. M., 2019. Comparison of Horticulture Performance and Genetic Diversity Based on RAPD Markers of Some Lemon and lime cvs in Egypt Middle East Journal of Agriculture Research. 08 (02): 624-637.

El-Mouei, R., W. Choumane and F. Dway, 2011b. Molecular characterization and genetic diversity in genus Citrus in Syria. Int. J. Agric. Biol., 13: 351-356.

Evritt, B.S., 1993.Cluster Analysis .Willey. New York, USA.

Faske, M., J.E. Backhausen, M. Sendker, M .Singer-Bayrle, R. Scheibe and A. Von Schaewen, 1997. Transgenic Tobacco Plants Expressing Pea Chloroplast Nmdh cDNA in Sense and Antisense Orientation (Effects on NADP-Malate Dehydrogenase Level, Stability of Transformants, and Plant Growth). Plant Physiol., 115: 705-715.

Federici, C.T., D.Q. Fang, R.W. Scora, and M.L. Roose, 1998. Phylogenetic relationships within the genus Citrus (Rutaceae) and related genera as revealed by RFLP and RAPD analysis. Theor. Appl. Genet., 94: 812-822.

Fernie, A.R., and E. Martinoia, 2009. Malate. Jack of all trades or master of a few? Phytochemistry, 70: $828-32$.

Giannakis, C.S., K.G.M. Buchel, S.P. Skene and N.S. Robinson, 1998. Chitinase and B1, 3 glucanase in Grapevine leaves a possible defense against powdery mildow infection. Aust. J. Grape. Res., 4:14-22.

Gulsen, O. and M.L. Roose, 2001. Lemons: Diversity and relationships with selected Citrus genotypes as Measured with Nuclear Genome Markers. J. Amer. Soc. Hort. Sci., 126(3): 309317.

Hamza, E. M., 2013. Genetic Diversity of Some Citrus Varieties Based onMicrosatellite and RAPD Molecular Markers in Egypt.World Journal of Agricultural Sciences 9 (4): 316-324.

Jonathan, F.W. and N.F. Weeden, 1990. Visualization and interpretation of plant isozymes. Isozymes in plant Biology. D.E.Soltis and P.S.Soltis (eds). London Chpman and Hall, pp.5-45.

Kortckamp, 2006. Expression analysis of defense related genes in Grapevine leaves after inoculation with a host and non host pathogen. Plant. Physiol. And Biochem. 44:58.

Laemmli, U.K, 1970. Cleavage of structural proteins during the assembly of the head of bacteriophage T4. Nature, 227: 680-685.

Longo .G.P. and J. G. Scandalios, 1969. Nuclear gene control of mitochondrial malic dehydrogenase in maize By Atomic Energy Commission Plant Research Laboratory, Michigan State University, East Lansing. PROC. N. A. S. 62.

Luro, F., J. Gatto, G. Costantino and O. Pailly , 2011. Analysis of genetic diversity in Citrus. Plant Genetic Resources 9(02).

Minarik, P., N. Tomaskova, M. Kollarova, and M. Antalik, 2002. Malate dehydrogenases-structure and function. Gen. Physiol. Biophys., 21: 257-65.

Nei, M. and W.H. Li, 1979. Mathematical model for studying genetic variation in terms of restriction endonucleases. Proceedings of the National Academy of Sciences of the United States of America, 76: 5269-5273.

Nicolosi, E., Z.N. Deng, A. Gentile, S .La Malfa, G. Continella, and E. Tribulato, 2000. Citrus phylogeny and genetic origin of important species as investigated by molecular markers. Theor. Appl. Genet., 100: 1155-1166.

Ramadugu, C., B.E. Pfeil, M.L. Keremane, R.F. Lee, I.J. Maureira-Butler, and M.L. Roose, 2013. A six nuclear gene phylogeny of Citrus (Rutaceae) taking into account hybridization and lineage sorting. PLoS One 8, e68410.

Robinson L.C, J.B Gibbs, M.S Marshall, I.S. Sigal and K Tatchell ,1987. a component of the RASadenylate cyclase pathway in Saccharomyces cerevisiae. Science 235(4793):1218-21.

Scora, R.W., 1988. Biochemistry, taxonomy and evolution of modern cultivated Citrus. Proc. Int. Soc. Citricult. VI. Congr. vol. 1. Margraf Publishers, Weikersheim, Germany, pp. 277-289.

Schena, et al., 1995. Schena M, Shalon D, Davis RW, Brown PO. Quantitative monitoring of gene expression patterns with a complementary DNA microarray. Science, 20; 270(5235):467-70.

Segent, K., C. Casar and S. Gustavo , 2004. Antimicrobial and insectidcidal proteinisolated from seeds of Clitoria ternfea a tropical Forage Legum. Plant Physiology and Biochemistry. 42:807818 . 
Togawa. T., W. A. Dunn, A.C. Emmons, J. Nagao and J.H .Willis, 2008. Developmental expression patterns of cuticular protein genes with the R\&R Consensus rom Anoph eles gambiae. Insect Biochem Mol Biol., 38 (5):508-519.

Studier, F.W., 1973. Analysis of Bacteriophage T4 early RNAs and proteins of slab gel. J.Mol.Bio. 79:237-248.

Tomaz, T., M. Bagard, I. Pracharoenwattana, P. Linden, C.P. Lee, A.J. Carroll, E. Stroher, S.M. Smith, P. Gardestrom, and A.H. Millar, 2010. Mitochondrial malate dehydrogenase lowers leaf respiration and alters photorespiration and plant growth in Arabidopsis. Plant Physiol., 154: 1143-57.

Uzun, A., T. Yesiloglu, I. Polat, Y. Aka-Kacar, O. Gulsen, B. Yildirim, O. Tuzcu, S. Tepe, I. Canan and S. Anil, 2011. Evaluation of genetic diversity in lemons and some of their relatives based on SRAP and SSR markers. Plant Mol. Biol. Rep., 29: 693-701.

Van Loon, I.C. and E.A. Van Strein, 1999. The families of pathogenesis-related proteins their activities and comparative analysis of PR. Type protein . Physiol.Mol.Plant pathol. 55.

Wang, C.L, X.P .Zhang., X.L. Fan., Y .Gao., Q.L, Zhu., C.K Zheng., T.F Qin., X.Q. Li., J.Y .Che.. M.W .Zhang, B .Yang, Y.G. Liu and K.J. Zhao.,2015. XA23 is an Executor R protein and confers broad- spectrum disease resistance in rice .Molecular Plant 8 ,290-302.

Wielgoss, A. and Kootekam,2008. Comparison in different Grapevine cultivar systems after inoculation with a host and non host pathogen. Vitis. 45:9-13.

Yamamoto, M., S. Konayashi, Y. Nakamura, and Y. Yamada, 1993. Phylogenic relationships of citrus revealed by RFLP analysis of mitochondrial and chloroplast DNA. Ikushugaku Zasshi 43: 355365.

Yao, Y.X., Q.L. Dong, H.Y. Zhai, C.X. You and Y.J. Hao, 2011 . The functions of an apple cytosolic malate dehydrogenase gene in growth and tolerance to cold and salt stresses. Plant Physiol. Biochem., 49: 257-64.

Yao, Y.X., M. Li, H. Zhai, C.X. You, and Y.J. Hao, 2011b. Isolation and characterization of an apple cytosolic malate dehydrogenase gene reveal its function in malate synthesis. J. Plant Physiol., 168: 474-480.

Yates, I.E., E.A. Carter and T.A. Wilkins, 1990. Seasonal variation in poly peptide profiles and cellular structure of pecan leaves. Journal of the American Society of Horticultural Science, 115: 924-929. 


\section{Appendix:}

Table 6: Sweet orange lemon and lime cvs genotypes characterized by negative and positive genotype-specific markers and their molecular sizes (bp) and total number of markers for each genotype using RAPD analysis.

\begin{tabular}{|c|c|c|c|c|c|c|c|c|c|c|c|c|c|c|c|c|c|c|c|}
\hline \multirow[b]{3}{*}{ Primers } & \multicolumn{4}{|c|}{ Balady orange } & \multicolumn{3}{|c|}{ Blood orange } & & \multicolumn{3}{|c|}{ Khalili orange } & \multicolumn{4}{|c|}{ Red Khalili orange } & \multicolumn{4}{|c|}{ Eurkea Lemon } \\
\hline & \multicolumn{2}{|c|}{$\mathbf{N}$} & \multicolumn{2}{|c|}{$\mathbf{P}$} & \multicolumn{2}{|c|}{$\mathbf{N}$} & \multicolumn{2}{|l|}{$\mathbf{P}$} & $\mathbf{N}$ & \multicolumn{2}{|c|}{$\mathbf{P}$} & \multicolumn{2}{|c|}{$\mathbf{N}$} & \multicolumn{2}{|c|}{$\mathbf{P}$} & \multicolumn{2}{|c|}{$\mathbf{N}$} & \multicolumn{2}{|c|}{$\mathbf{P}$} \\
\hline & $\begin{array}{c}\text { Size } \\
\text { bp }\end{array}$ & No & $\begin{array}{c}\text { Size } \\
\text { bp }\end{array}$ & No & $\begin{array}{l}\text { Size } \\
\text { pb }\end{array}$ & No & $\begin{array}{l}\text { Size } \\
\text { bp }\end{array}$ & No & $\begin{array}{l}\text { Size } \\
\text { pb }\end{array}$ & $\begin{array}{l}\text { Size } \\
\text { pb }\end{array}$ & No & $\begin{array}{l}\text { Size } \\
\text { pb }\end{array}$ & No & $\begin{array}{l}\text { Size } \\
\text { pb }\end{array}$ & No & $\begin{array}{l}\text { Size } \\
\text { pb }\end{array}$ & No & Size pb & No \\
\hline RAPD2 & & & & & & & & & & & & & & $\begin{array}{l}700 \\
670\end{array}$ & 2 & $\begin{array}{l}850 \\
240\end{array}$ & 2 & & \\
\hline \multicolumn{20}{|l|}{ RAPD4 } \\
\hline RAPD6 & & & $\begin{array}{l}940 \\
350\end{array}$ & 2 & & & 580 & 1 & & 600 & 1 & & & & & & & 560530 & 2 \\
\hline RAPD8 & & & & & & & 140 & 1 & & 110 & 1 & & & & & & & 470400360320280 & 5 \\
\hline \multicolumn{20}{|l|}{ RAPD10 } \\
\hline Es10A26 & & & & & & & 340 & 1 & & & & & & & & & & & \\
\hline P1 & & & & & & & 450 & 1 & & & & & & & & & & & \\
\hline S1 & & & 470 & 1 & & & & & & & & & & & & & & & \\
\hline S2 & & & & & & & & & & & & & & & & & & 750330 & 2 \\
\hline \multicolumn{20}{|l|}{$\begin{array}{c}\text { Total bands for each } \\
\text { cultivar }\end{array}$} \\
\hline Ible 6: Cont. & & \multicolumn{5}{|c|}{$\begin{array}{ll}\text { Shaery Lime } \\
\end{array}$} & \multicolumn{4}{|c|}{ Egyptian lime } & \multicolumn{5}{|c|}{ Sweet lemon } & Tot: & No. $\mathbf{N}+\mathrm{P}$ & \multirow{2}{*}{\multicolumn{2}{|c|}{ Total No. of N\&P }} \\
\hline & & \multicolumn{2}{|c|}{$\mathbf{N}$} & & $\mathbf{P}$ & & $\mathbf{N}$ & V & $\mathbf{P}$ & & & $\mathbf{N}$ & & $\mathbf{P}$ & & $\mathbf{N}$ & $\mathbf{P}$ & & \\
\hline Primers & & $\begin{array}{c}\text { Size } \\
\text { bp }\end{array}$ & No & & $\begin{array}{l}\text { Size } \\
\text { bp }\end{array}$ & No & Size bp & No & Size bp & No & $\begin{array}{l}\text { Size } \\
\text { bp }\end{array}$ & No & & $\begin{array}{l}\text { Size } \\
\text { bp }\end{array}$ & No & & & & \\
\hline RAPD2 & & 340 & 1 & & 450 & 1 & & & $\begin{array}{c}300140 \\
120\end{array}$ & 3 & & & & & & 2 & 7 & 9 & \\
\hline RAPD4 & & & & & $\begin{array}{l}480 \\
300 \\
\end{array}$ & 2 & 350 & 1 & & & & & & & & 2 & 4 & 6 & \\
\hline RAPD6 & & & & & 1000650 & 2 & & & & & & & & & & & 8 & 8 & \\
\hline RAPD8 & & 500 & 1 & & $\begin{array}{c}1400450 \\
260\end{array}$ & 3 & & & & & & & & & & 1 & 10 & 11 & \\
\hline RAPD10 & & & & & 330 & 1 & & & & & & & & & & & 1 & 1 & \\
\hline Es10A26 & & & & & & & & & & & & & & & & & 1 & 1 & \\
\hline P1 & & & & & $\begin{array}{l}350 \\
260 \\
180 \\
130 \\
\end{array}$ & 4 & & & & & & & & & & & 5 & 5 & \\
\hline S1 & & & & & & & & & & & & & & & & & 1 & 1 & \\
\hline $\begin{array}{r}\text { S2 } \\
\end{array}$ & & & & & & & & & & & & & & & & & 2 & 2 & \\
\hline Total bands for eacl & var & & & & & & & & & & & & & & & 5 & 39 & 44 & \\
\hline
\end{tabular}

